Интернет-журнал «Отходы и ресурсы» https://resources.today

Russian Journal of Resources, Conservation and Recycling

2018, №3, Том 5 / 2018, No 3, Vol 5 https://resources.today/issue-3-2018.html

URL статьи: https://resources.today/PDF/02NZOR318.pdf

DOI: 10.15862/02NZOR318 (http://dx.doi.org/10.15862/02NZOR318)

Ссылка для цитирования этой статьи:

Воробьева В.С., Астратова Г.В. Анализ систем ливневой и бытовой канализации: технические, организационные и экономические аспекты // Интернет-журнал «Отходы и ресурсы», 2018 №3, https://resources.today/PDF/02NZOR318.pdf (доступ свободный). Загл. с экрана. Яз. рус., англ. DOI: $10.15862 / 02 N Z O R 318$

For citation:

Vorobiyova V.S., Astratova G.V. (2018). Analysis of storm water systems and sanitary sewers: technical, organizational and economic aspects. Russian Journal of Resources, Conservation and Recycling, [online] 3(5). Available at: https://resources.today/PDF/02NZOR318.pdf (in Russian). DOI: 10.15862/02NZOR318

\title{
УДК 55
}

Воробьева Виктория Сергеевна

ФГБОУ ВО «Уральский государственный экономический университет», Екатеринбург, Россия

Колледж

Студентка

E-mail: vorobeva053@gmail.com

\section{Астратова Галина Владимировна}

ФГБОУ ВО «Уральский государственный экономический университет», Екатеринбург, Россия Зав. кафедрой «Экономики жилищного, коммунального хозяйства и энергетики» Доктор экономических наук, кандидат технических наук, профессор

E-mail: galina_28@mail.ru; astratova@yahoo.com ORCID: http://orcid.org/0000-0002-3579-4440 РИНЦ: https://elibrary.ru/author_profile.asp?id=263754 Researcher ID: http://www.researcherid.com/rid/C-3514-2015

\section{Анализ систем ливневой и бытовой канализации: технические, организационные и экономические аспекты}

Аннотация. Проведён анализ систем ливневой и бытовой канализации на основе исследования некоторых технических, организационных и экономических аспектов деятельности систем. Показано, что на текущий момент проблема очистки сточных вод чрезвычайно актуальна. Установлено, что многие компании сбрасывают большое количество сточных вод, которые фактически не обрабатываются в местных водохранилищах.

Выявлено, что в исследуемой сфере в РФ в целом и в Свердловской области, в частности, наблюдается невыполнение нормативов работы очистных сооружений. Ключевыми причинами данной ситуации являются следующие основные факторы:

1. физический износ оборудования, неудовлетворительное техническое состояние очистных сооружений;

2. несоответствие состава поступающих сточных вод и систем очистки;

3. отсутствие сооружений по доочистке сточных вод;

\footnotetext{
${ }^{1}$ Социальные сети: https://vk.com/id8134129, https://www.facebook.com/astratova?ref=bookmarks
} 
4. недогруз по гидравлике и неравномерная подача сточных вод;

5. нарушение технико-технологических режимов эксплуатации очистных сооружений;

6. несвоевременное проведение ремонтных и реставрационных работ, замены вышедших из строя оборудования, узлов и деталей;

7. отсутствие достаточного финансирования отрасли, финансирование по «остаточному принципу»;

8. нехватка высококвалифицированных кадров для осуществления грамотной эксплуатации очистных сооружений;

9. и др.

Авторы полагают, что в целях улучшения качества сбрасываемых сточных вод, уменьшения их влияния на водные объекты, сокращения объёма выброса стоков необходимы следующие первоочередные меры:

a) строительство новых, реконструкция и расширение действующих очистных сооружений;

б) строительство локальных очистных сооружений, блоков доочистки;

в) ввод в эксплуатацию систем оборотного и повторного водоснабжения;

г) выявление дополнительных источников финансирования системы очистных сооружений, в том числе - за счёт концессионных соглашений, создания частногосударственных партнёрств;

д) формирование «государственного заказа» и выделения целевых бюджетных мест в колледжах и вузах на обучение по специальностям, связанным с ЖКХ, водопотреблением и водоотведением.

Ключевые слова: очистка сточных вод; экологическая опасность; водоотводные системы города; ливневые стоки; бытовые стоки; очистные сооружения; ливневая и бытовая канализация; Свердловская область; водные ресурсы

Актуальность заявленной проблематики обусловлена тем, что в нашей стране длительное время не уделяли должного внимания работе систем ливневой и бытовой канализации. Это привело не только к обветшанию материально-технической базы отрасли, влекущей за собой затопление улиц и газонов, заболачивание парковых зон, но и к тому, что дренажные системы зачастую просто отсутствуют, в связи с чем проведение обновления, реконструкции и строительства новых систем становится невозможным. Немаловажно и то, что на текущий момент как никогда актуальной становится проблема нехватки чистой пресной воды $[14,15,16]$ (рис. 1). 


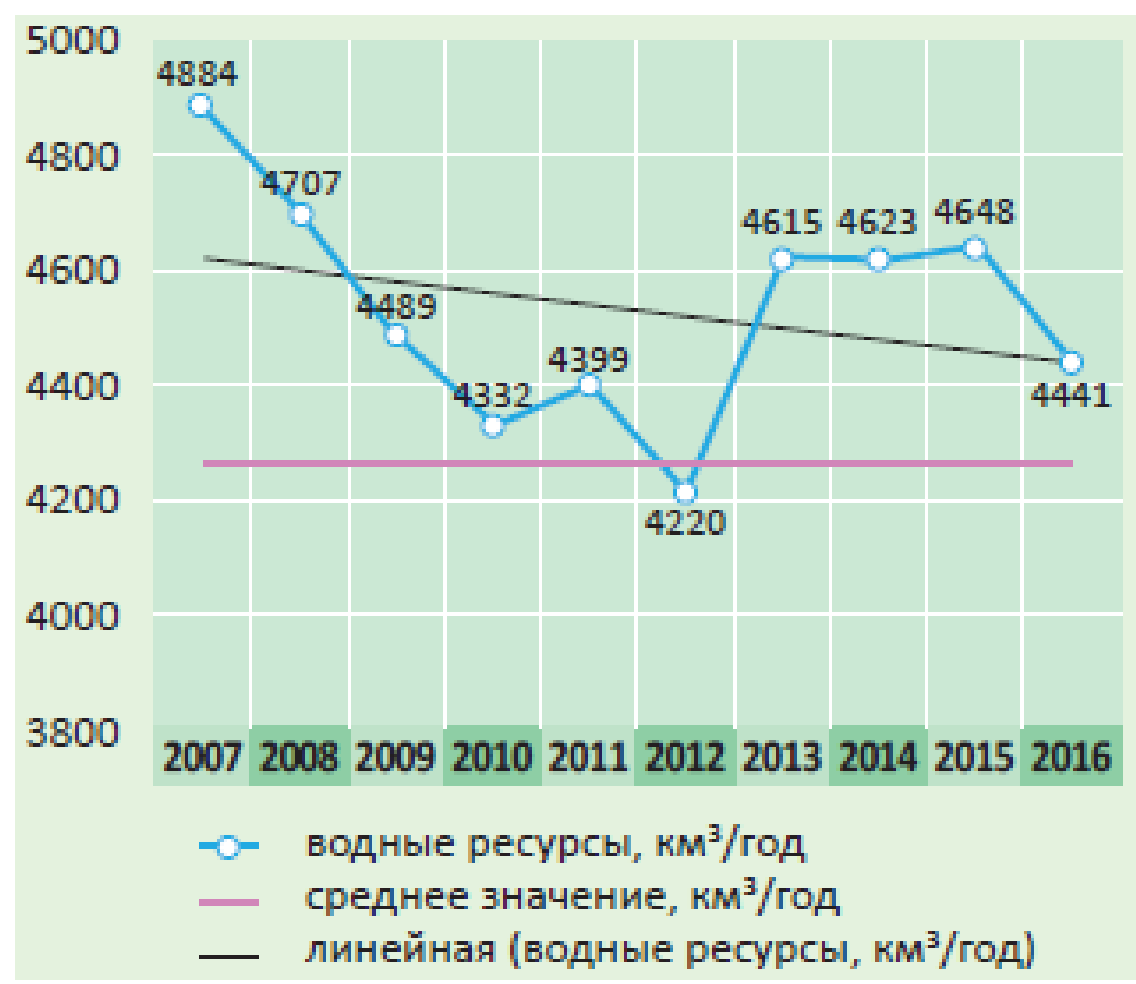

Рисунок 1. Динамика водных ресурсов Российской Федерации [15, с. 52]

Необходимо отметить, что общий забор воды из водных объектов РФ за последние годы имел тенденцию снижающего вектора, хотя в отдельные периоды времени эта тенденция весьма ощутимо варьировала (табл. 1).

Если говорить о динамике удельной водоёмкости ${ }^{2}$ России, то итоги соответствующих расчётов в текущих ценах в сводном и конкретном виде представлены в табл. 2.

Таблица 1

Основные показатели водопользования по России (по данным Росводресурсов), км ${ }^{3}[15$, c. 53]

\begin{tabular}{|c|c|c|c|c|c|c|c|}
\hline Показатель & 2000 г. & 2005 г. & 2010 г. & 2013 г. & 2014 г. & 2015 г. & 2016 г. \\
\hline $\begin{array}{l}\text { Забор воды (вкл. Морскую) из природных } \\
\text { источников }\end{array}$ & 85,9 & 79,5 & 79,0 & 69,9 & $708 * *$ & 68,6 & 69,5 \\
\hline в т. ч. водозабор для использования* & 75,9 & 69,3 & 69,7 & 61,0 & 63,2 & 60,8 & 61,9 \\
\hline $\begin{array}{l}\text { в том числе: из поверхностных } \\
\text { источников }\end{array}$ & 65,7 & 60,2 & 61,7 & 53,35 & 54,5 & 51,9 & 52,4 \\
\hline из подземных источников & 10,2 & 9,1 & 8,0 & 7,65 & 8,7 & 8,9 & 9,5 \\
\hline Использовано свежей воды, всего & 66,9 & 61,3 & 59,5 & 53,6 & 56,0 & 54,6 & 54,7 \\
\hline $\begin{array}{l}\text { в том числе на нужды: хозяйственно- } \\
\text { питьевые }\end{array}$ & 13,6 & 12,3 & 9,6 & 8,7 & 8,5 & 8,2 & 7,9 \\
\hline производственные & 38,8 & 36,5 & 36,4 & 31,5 & 32,4 & 31,4 & 31,2 \\
\hline из них: питьевого качества & 3,7 & 3,7 & 3,8 & 2,6 & 2,54 & 2,42 & 2,77 \\
\hline $\begin{array}{l}\text { для орошения, обводнения пастбищ и } \\
\text { сельхозводоснабжения }\end{array}$ & $12,6^{* * *}$ & 10,4 & 8,3 & 7,0 & 7,6 & 7,2 & 7,1 \\
\hline $\begin{array}{l}\text { Расходы в системах оборотного и повторно- } \\
\text { последовательного водоснабжения, всего }\end{array}$ & 133,5 & 135,5 & 140,7 & 138,5 & 136,6 & 138,8 & 137,9 \\
\hline
\end{tabular}

${ }^{2}$ Отношение водозабора к ВВП. 


\begin{tabular}{|c|c|c|c|c|c|c|c|}
\hline Показатель & 2000 г. & 2005 г. & 2010 г. & 2013 г. & 2014 г. & 2015 г. & 2016 г. \\
\hline $\begin{array}{l}\text { в том числе: повторного и } \\
\text { последовательного водоснабжения }\end{array}$ & 6,4 & 6,7 & 14,0 & 7,42 & 7,70 & 7,84 & 7,55 \\
\hline $\begin{array}{l}\text { Процент экономии воды на } \\
\text { производственные нужды за счет } \\
\text { оборотного и последовательного } \\
\text { водоснабжения }\end{array}$ & 77 & 78 & 79,4 & 81 & 81 & 81,5 & 81,6 \\
\hline Потери при транспортировке & 8,5 & 8,0 & 7,7 & 7,0 & 7,7 & 6,8 & 6,8 \\
\hline $\begin{array}{l}\text { Водоотведение (сброс) в поверхностные } \\
\text { природные водные объекты, без транзитной } \\
\text { воды }\end{array}$ & 55,6 & 50,9 & 49,2 & 42,9 & 43,9 & 42,9 & 42,9 \\
\hline $\begin{array}{l}\text { в том числе сброс: загрязненных сточных } \\
\text { вод }\end{array}$ & 20,3 & 17,7 & 16,5 & 15,2 & 14,8 & 14,4 & 14,7 \\
\hline из них: без очистки & 4,5 & 3,4 & 3,4 & 2,96 & 3,23 & 3,11 & 3,42 \\
\hline недостаточно очищенных & 15,7 & 14,3 & 13,1 & 12,2 & 11,54 & 11,31 & 11,30 \\
\hline нормативно-чистых сточных вод & 32,9 & 31,0 & 30,8 & 26,0 & 27,3 & 26,5 & 26,2 \\
\hline нормативно-очищенных сточных вод & 2,4 & 2,2 & 1,88 & 1,71 & 1,84 & 1,90 & 1,98 \\
\hline
\end{tabular}

*Без учета откачиваемых и неиспользуемых шахтно-рудничных вод, транзитной воды для перераспределения стока и некоторых других видов водозабора для иелей, не связанных с непосредственным водопотреблением (порядка 10 км³/год); с учетом морской воды (от 4 до $6 \mathrm{kм}^{3} /$ год); **Включая почти 1,4 тыс. водопользователей и около 0,4 млрд м³ водозабора по Крымскому федеральному округу. Остальные показатели таблииы также даны с учетом

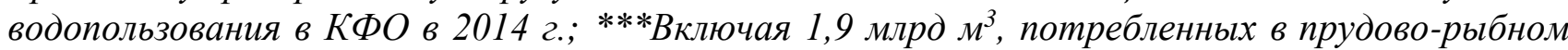
хозяйстве.

Таблица 2

Динамика водоёмкости (объёма водозабора на единицу ВВП) в России* (по данным Росводресурсов) [15, с. 54]

\begin{tabular}{|c|c|c|c|}
\hline Год & $\begin{array}{l}\text { Общий забор воды из природных } \\
\text { источников на все нужды, млн м }{ }^{3}\end{array}$ & $\begin{array}{l}\text { ВВП, в текущих } \\
\text { ценах, млн руб. }\end{array}$ & $\begin{array}{c}\text { Водозабор к ВВП, в текущих } \\
\text { ценах, м³/тыс. руб. }\end{array}$ \\
\hline 2000 & 85940,4 & 7305646,0 & 11,76 \\
\hline 2005 & 79472,5 & 21609766,0 & 3,68 \\
\hline 2006 & 79273,5 & 26917201,0 & 2,95 \\
\hline 2007 & 79985,3 & 33247513,0 & 2,41 \\
\hline 2008 & 80272,3 & 41276849,0 & 1,94 \\
\hline 2009 & 75401,0 & 38807219,0 & 1,94 \\
\hline 2010 & 78955,5 & 46308541,0 & 1,70 \\
\hline 2011 & 75220,5 & 60282541,0 & 1,25 \\
\hline 2012 & 72052,6 & 68163883,0 & 1,06 \\
\hline 2013 & 69924,7 & 73133895,0 & 0,96 \\
\hline 2014 & 70806,8 & 79199659,0 & 0,89 \\
\hline 2015 & 68614,24 & 83232618,0 & 0,82 \\
\hline 2016 & 69498,54 & 86043649,0 & 0,81 \\
\hline
\end{tabular}

*В 2014-2015 г2. с учетом Крымского ФО. Данные о ВВП за 2010-2016 г2. не полностью сопоставимы с данными за предшествующие годы

Необходимо подчеркнуть, что проблема нехватки чистой пресной воды могла бы быть успешно разрешена также посредством улучшения эффективности систем очистки ливневой и бытовой канализации.

Вместе с тем, из-за недостаточно эффективной работы систем водопотребления и водоотведения данная проблема на текущий момент решается весьма асимметрично. Например, как видно из имеющихся данных по Свердловской области, за последние годы 
наблюдается тенденция снижения и водозабора ${ }^{3}$ (рис. 2), и, соответственно, снижения объёмов водоотведения (рис. 3).

Рассмотрим некоторые технические и организационные аспекты работы систем ливневой и бытовой канализации.

Как известно, сточные воды представляют собой атмосферную воду и осадки, в том числе - талая вода и дождевая вода, а также - вода из промышленных предприятий и густонаселенных районов, которые были введены в водохранилища через канализационную систему или под действием силы тяжести в воду и улицы, где характеристики ухудшаются в результате деятельности человека.

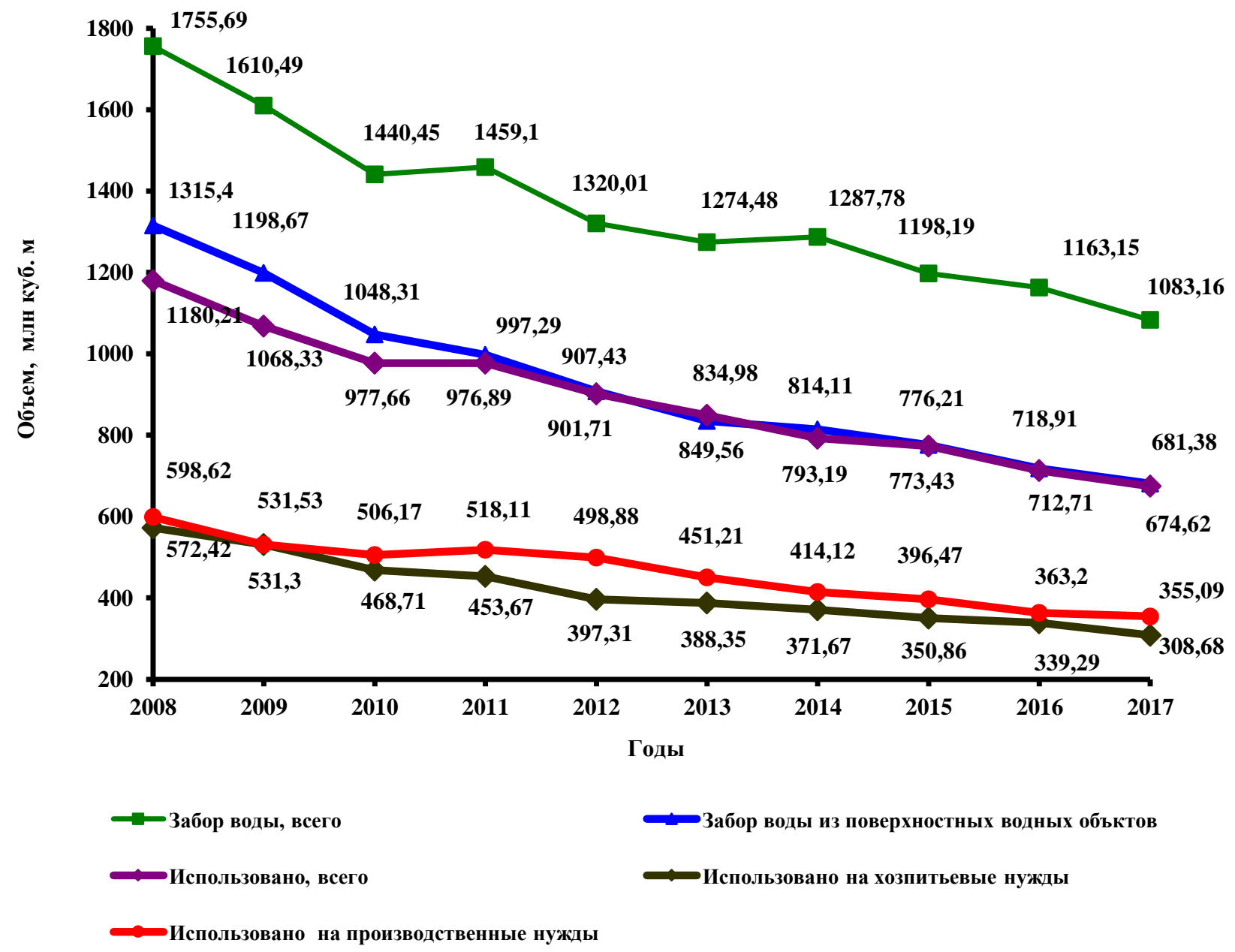

Рисунок 2. Динамика забора и использования водных ресурсов Свердловской областью (млн куб. м) [16, с. 24]

Сточные воды подразделяются на три группы [12]:

- $\quad$ Бытовые - из жилых и общественных зданий, семейных домов и промышленных предприятий.

- Промышленные - вода используется в технических процессах, которые не отвечают требованиям качества. Вода в этой категории содержит воду, закачиваемую на землю во время горных работ.

\footnotetext{
${ }^{3}$ Преимущественно - из-за сокращения производственных мощностей.
} 
- $\quad$ Ливневые - дождевая и талая вода, от городского полива улиц, выброс атмосферы из фонтана и дренаж.

Также используется концепция городского дренажа, это смесь бытовых сточных вод и промышленных сточных вод. Бытовые, промышленные и ливневые сточные воды могут очищаться совместно или по отдельности. Наиболее широко используются общие и независимые канализационные системы. В системе всех расплавов все три категории дренажа отправляются на перерабатывающий завод через общую сеть труб и каналов за пределами городской территории. Очистная система состоит из нескольких сетей труб и каналов. Один из них обеспечивает дождевые и незагрязненные промышленные сточные воды, одну или несколько сетей - домашние хозяйства и загрязненные промышленные сточные воды.

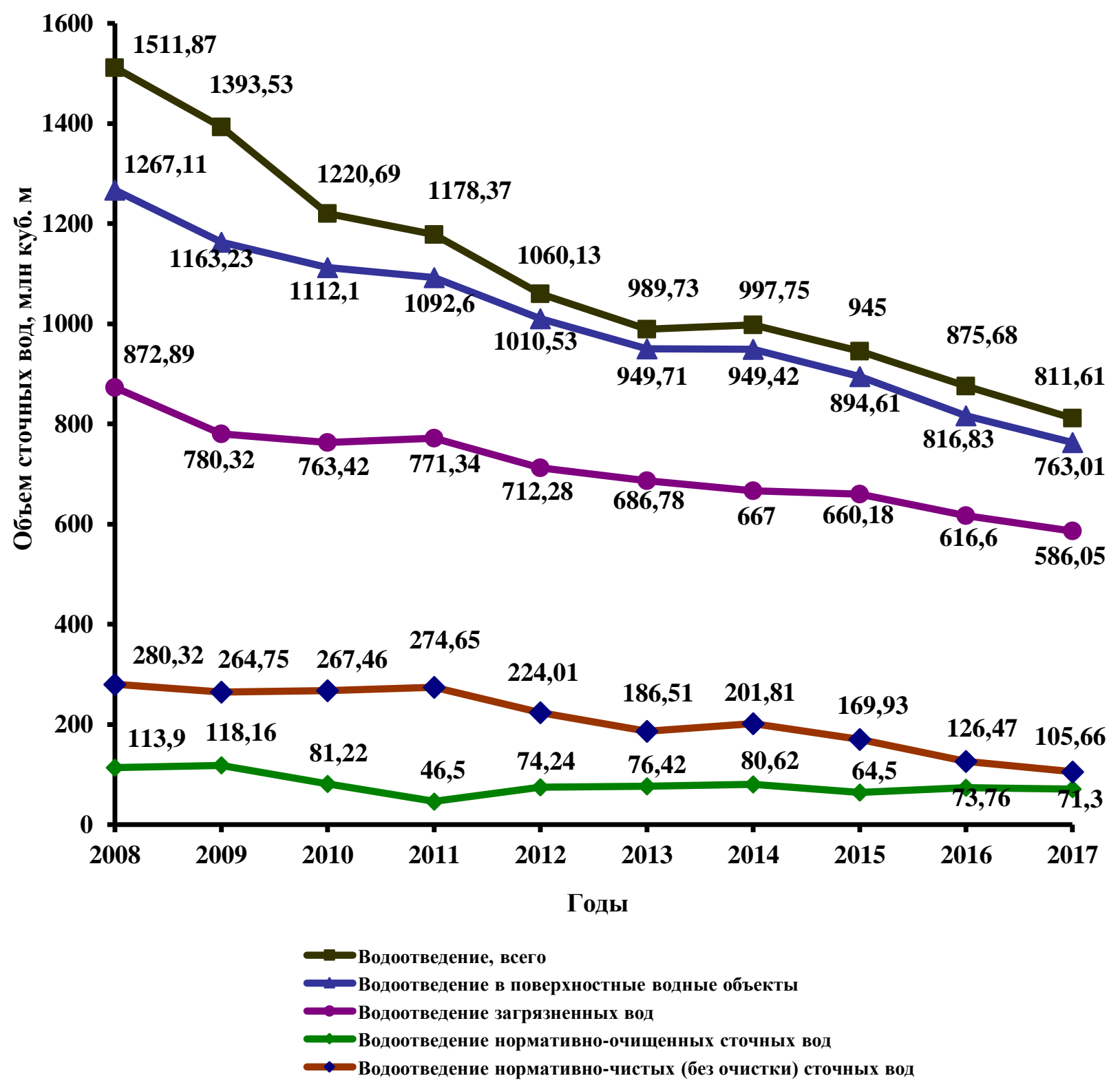

Рисунок 3. Динамика водоотведения по Свердловской области (млн куб. м) [16, с. 25]

Канализация является сложной гетерогенной смесью, содержащая в себе микропримеси органического и неорганического проявления, нерастворенные в коллоидном и растворенном состоянии. 
Степень загрязнения сточных вод оценивается концентрацией. Массовая смесь на единицу объема мг/л или г/куб. м. Зачастую отдельно изучается структура сточных вод по санитарно-химическим и микробиологическим показателям $[14,15,16]$.

Так, в 2014 г. в централизованных системах водоснабжения Свердловской области было зафиксировано несоответствие нормативам по санитарно-химическим показателям в 13,9 \% взятых проб, по микробиологическим показателям - в 4,9 \% проб (рис. 4).

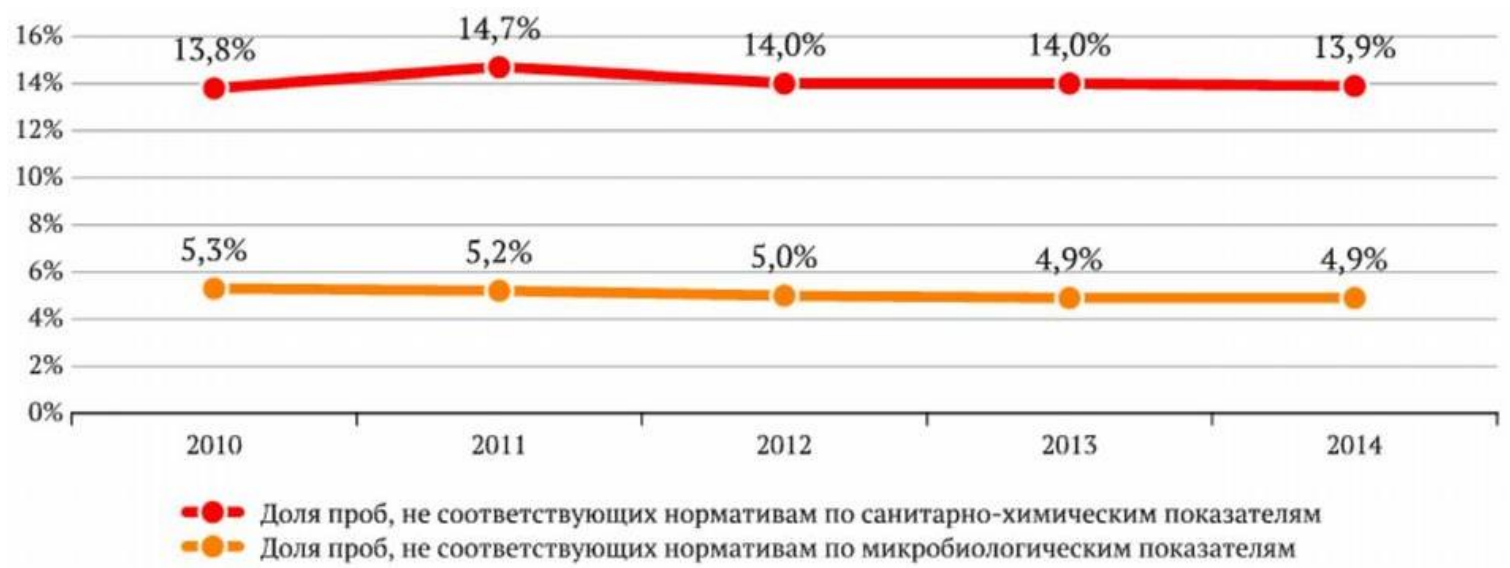

Рисунок 4. Качество водьл в Свердловской области. Централизованные системы водоснабжения [14]

В нецентрализованных системах водоснабжения Свердловской области не соответствовало нормативом качество в 37,8 \% проб по санитарно-химическим показателям и в 23,2 \% проб по микробиологическим показателям (рис. 5).

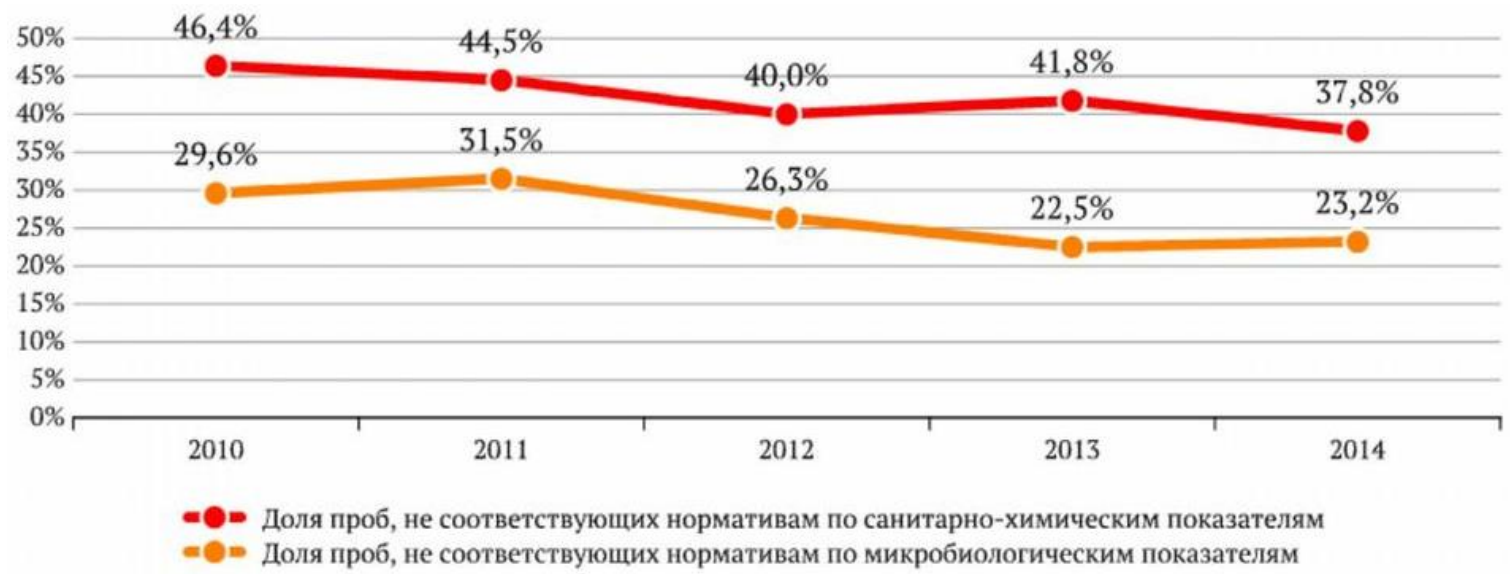

Рисунок 5. Качество воды в Свердловской области. Нецентрализованные системы водоснабжения [14]

В 2017 г. к классу «загрязненная» на территории Свердловской области относилась вода водных объектов в $15 \%$ створов пунктов наблюдений, к классу «грязная» - в 79 \%, к классу «экстремально грязная» - в $6 \%$ створов [16, с. 27].

Гигиеническое и химическое изучение состава воды проводится по нахождению в ней следующих показателей: ХПК (показатель содержания органической материи в воде); БПК (скопление органического соединения, окисленного биологическими средствами); Концентрация твердых веществ, воздействие среды; Плотность цвета, степень минерализации, концентрация питательных веществ и так далее. Более затруднительным является состав сточных вод промышленных предприятий [11]. 


\section{Промышленные сточные воды}

На состав производственных вод влияет [11]:

- $\quad$ Типы перерабатываемого сырья.

- $\quad$ Технический процесс производства.

- $\quad$ Реагенты, применяемые в производстве.

- $\quad$ Временные изделия и продукты производства.

- Состав первоначальной используемой воды.

- $\quad$ Местные условия и многое другое.

Рациональная схема не только оценивает режим составления состава дренажа и разработки сточных вод, но также возможность повторного использования общего стока промышленных предприятий, а также токсичных веществ или биологических ингибиторов, особенно сточные воды отдельных установок и оборудования, особенно если они могут быть включены.

В дополнение к определению основных санитарно-химических показателей в промышленных сточных водах определяется концентрация конкретного ингредиента, содержание которого определяется техническими правилами производства и номенклатурой используемого вещества.

Загрязненные промышленные воды делятся на три группы [11]:

- Стоки, загрязненные минеральными веществами.

- $\quad$ Стоки, загрязненные органическими примесями.

- Стоки, загрязненные минеральными и органическими веществами.

Промышленные стоки могут иметь разную плотность загрязняющих примесей, степень агрессии и т. д. Состав промышленных сточных вод очень отличается. Поэтому необходимо досконально обосновать выбор надежного и эффективного метода очистки для всех видов случая. Приобретение норм расчета и технических правил очистки сточных вод и осадка запрашивают очень длительных научных изучениях как в лабораторных, так и в полупроизводственных условиях.

Количество промышленных сточных вод определяется в зависимости от возможностей предприятий по мере расширения стандартов водопотребления и санитарии в промышленности.

Потребление воды - это необходимое количество воды, необходимое для производственного процесса, основанного на научных основанных на фактических данных расчетах и передовой практике [10]. Увеличение потребления воды включает в себя стоимость всей воды в компании. Стандарты потребления промышленных сточных вод используются для проектирования вновь построенной и реконструированной существующей дренажной системы промышленного назначения. С расширенными нормами мы можем оценить рациональность использования воды во всех действующих компаниях.

В рамках инженерной коммуникации промышленных предприятий, существует немного водоотводных сетей. Незагрязненные подогретые стоки подаются на охлаждающее устройство (градирни, охлаждающий пруд), а далее рекуперируется в систему циркуляционного водоснабжения. После того как загрязненные сточные воды поступают на очистные 
сооружения, некоторая часть очищенных стоков подается в систему циркуляционной воды и попадает в хранилище, состав которого соответствует нормативным требованиям ${ }^{4}$.

Эффективность пользования воды на производственных предприятиях оценивается по таким показателям, как переработанное количество используемой воды, коэффициент использования, коэффициент потерь. Для промышленных предприятий проводится водный баланс, включает различные виды потерь, дополнительные затраты на воду для компенсации системы и т. д.

Урегулирование и проектирование вновь построенной и восстановленной канализационной системы для промышленных предприятий утверждается в заранее определенном порядке для разработки и развертывания национальных экономик, отраслей и планов развития и развертывания производительных сил в экономическом регионе. Это необходимо сделать на основе этого. При выборе систем и схем очистки сточных вод необходимо учитывать возможность укрепления работы с учетом технических, экономических и санитарных оценок существующих сетей и сооружений.

При выборе системы и схемы водоотведения промышленных предприятий нужно учитывать следующие факторы [11]:

- $\quad$ Требования к качеству воды, используемой в различных технических процессах.

- Качество воды, состав, свойства, режим водоотведения отдельных канализационных систем.

- $\quad$ Возможность сократить количество загрязненных промышленных сточных вод путем оптимизации технологического процесса производства.

- $\quad$ Возможность утилизации промышленных сточных вод в системе водоснабжения типа циркуляции или технических нужд другой продукции, которая может использовать воду низкого качества.

- Целесообразность извлечения и использования веществ, содержащихся в сточных водах.

- Возможность и осуществимость совместной утечки и очистки сточных вод близко расположенных промышленных предприятий, и возможность комплексного решения очистки сточных вод промышленных предприятий и сёл.

- $\quad$ Возможность использования в технологическом процессе очищенных бытовых сточных вод.

- $\quad$ Возможность и удобство использования бытовых промышленных сточных вод для орошения сельскохозяйственных и технических культур.

- Целесообразность локальной очистки сточных вод отдельных цехов предприятия.

- Самоочищающаяся емкость резервуара, условия стоков для него и необходимая степень очистки.

• Целесообразность применения того или иного метода очистки.

${ }^{4}$ ГОСТ 12.3.006-75 ССБТ. Эксплуатация водопроводных и канализационных сооружений и сетей. Общие требования безопасности. 


\section{Бытовые сточные воды}

Загрязнение бытовых стоков делятся на неорганические и органические вещества, присутствующие в растворенных и взвешенных формах в жидкостях. Кроме того, микроорганизмы, которые способствуют разложению органического вещества и вызывают анаэробную ферментацию в сточных водах.

Важной особенностью бытовых сточных вод является биоразлагаемость (восприимчивость к биологической деградации или биоочистка) в зависимости от существующего баланса бактерий (азота и фосфора) [19].

Общее содержание азота в бытовых сточных водах является максимальным 15-20\% БПК 5. Более высокое содержание азота указывает на наличие промышленных сточных вод 5 .

Аналогичным образом, бытовые отходы включаются в сточные воды в виде раздавленной формы. Как только они входят в кухонную раковину, они сбрасываются в канализационную систему (которая запрещена во Франции). Такие отходы не задерживаются решеткой, а загрузка на обогатительной фабрике значительно возрастает (в некоторых городах США БПК 5 и взвешенные твердые вещества в сточных водах почти удваиваются).

Присутствие биологически слабо разлагаемых химических и биологических ингибиторов увеличивает отношение ХПКЗ/БПК4 (теоретически) к ХПК/ БПК (по существу).

Для того, чтобы работа очистки продолжалась нормально, стоки обязаны поступать в лечебное учреждение в свежем состоянии в достаточной степени. Испорченные сточные воды токсичны для этого процесса и должны подвергаться предварительной аэрации или прехлорированию перед первоначальным осаждением.

Бытовые канализационные трубы характеризуются потреблением, содержанием взвешенных веществ, биохимическим потреблением кислорода.

Если необработанные сточные воды содержат значительное количество промышленных сточных вод (от скотобойни, молочных ферм и т. д.), изменения концентрации загрязняющих веществ могут стать более серьезными, чем при наличии только бытовых сточных вод. Это необходимо учитывать при проектировании структуры.

Токсичность и ингибирование. Наличие ионов тяжелых металлов, таких как $\mathrm{Cu} 2+, \mathrm{Cr} 6+$, $\mathrm{Cd} 2+$ и др., даже в небольших концентрациях $(0,1$ мг/л), может подавлять активность бактерий [13].

Кроме этого, множественные токсичные вещества спускаются в канализацию, в частности природные воды под запретом закона (цианид, циклические гидроксильные соединения и т. д.). Часть лекарств может нанести вред бактериальной долговечности (антибиотики).

В части равновесия питательных веществ в сточных водах, то азот и фосфор часто могут быть недостаточными. В некоторых случаях необходимо прибавлять питательные компоненты, чтобы вернуть соотношение БПК5/ЛГ к 20 и БКДД 100, которые крайне нужны для биологической обработки.

Нехватка равновесия способна вызвать дезорганизацию биологического процесса, сопровождающего набухание активированного ила, и уменьшение эффективности очистки. Эффективность очистки может снижаться, если концентрация соли высокая.

\footnotetext{
${ }^{5}$ Методические указания по разработке нормативов предельно допустимых сбросов вредных веществ в поверхностные водные объекты.
} 
Температурные колебания также влияют на процесс удаления бытовых сточных вод.

\section{Виды загрязнителей}

Главными очагами загрязнения, а также являющиеся одновременно основными пользователями очищенной воды, относятся промышленные предприятия, сельские хозяйства и бытовые хозяйства. К основополагающим видам засорения относят химическое, физическое, биологическое и тепловое.

Химическое загрязнение - это проникновение в водовместилище с пресной водой разных химических отходов, нужных для промышленных производств и сельского хозяйства. Преимущественно стоит отметить загрязнение сочетаниями тяжелых металлов, нефтепродуктами, нитратами. При биологическом загрязнении множеством химических веществ (преимущественно азотом и фосфором) будет создана благоприятная среда для определенных организмов, а загрязнение водоема такими соединениями ведет к превращению водоема в болото.

В связи с физическим загрязнением в водоемы поступают нерастворимые примеси: глина, разнообразный мусор и песок.

Тепловое загрязнение относят в особую форму, потому что главным засоряющим элементом оказывается тепловая энергия, непрямо оказывающая влияние на все окружающую среду. Вспомогательный нагрев водоема сможет очень сильно поменять биологические процессы в нем, что ведет к уничтожению огромного количества его обитателей, или, наоборот, может являться причиной большого роста простейших бактерий и водорослей, потребность зачищения водоема от которых может очень сильно затруднить последующий процесс водоподготовки. Однако нужно подчеркнуть, что тепловое загрязнение может проявить и благоприятное воздействие на воду, поэтому данное понятие является условным, и оценивается индивидуально для каждого случая очистки. В сточных водах имеется сложная смесь твердых и растворенных веществ, которые присутствуют в очень малых концентрациях. На очистных сооружениях концентрации всех этих веществ снижаются до приемлемого уровня или химически трансформированных вредных веществ в безопасные соединения. Схема установки очистки зависит от степени загрязнения и количества очищенных сточных вод, а также от экономических и экологических соображений. Большинство установок по очистке воды имеют много общего.

\section{Бытовые сточные воды}

Бытовые стоки имеют обширную группу канализаций, создаваемых бытовыми объектами, включая объекты, связанные с человеческой жизнью, такие как отдельные дома, гостиницы, предприятия общественного (массового) питания, жилые и развлекательные центры, прачечные, ванные комнаты и т. д. Внутренние воды близки к высококачественной воде от сельскохозяйственных компаний, таких как сельскохозяйственные заводы и животноводческие фермы.

Среди бытовых стоков выделяют два основных типа ${ }^{6}$ :

- $\quad$ Серые и черные стоки.

- $\quad$ Стоки от индивидуального жилого дома.

${ }^{6}$ «Внутренний водопровод и канализация зданий». Свод правил 2016 г. 


\section{Серые и черные стоки}

Серые стоки представляют собой смесь различного качества сточных вод, проистекающих из одного объекта - жилого дома, за исключением туалетной воды, образованной между пользователями воды. Когда вода добавляется к серой воде из туалета, полученная смесь называется черным сливным отверстием. Различные растворы отходов зависят главным образом от содержания органических веществ. В целом, качественный состав различных вод практически не меняется. Это устраняет необходимость отдельно рассматривать состав черного и серого дренажа. Загрязнение бытовых сточных вод подразделяется на две категории: химические вещества и биологическое загрязнение.

Химические вещества - загрязняющие вещества присутствуют в сточных водах в растворенной форме с различным водо-нерастворимым составом частиц. Основные формы нахождения этих веществ и их происхождение показаны в табл. 3.

Из данных табл. 3 заметно, что валовой состав сточных вод представлен минеральными и органическими веществами - загрязнителями сточной воды. Органические вещества составляют $58 \%$, а минеральные - $42 \%$ от общей массы примесей. Данный состав органических веществ бытовых стоков можно представить также с помощью табл. 4.

Таблица 3

Основные формы нахождения химических веществ, загрязнителей бытовых сточных вод и их происхождение

\begin{tabular}{|c|c|c|c|c|c|}
\hline \multirow{3}{*}{ Происхождение } & \multicolumn{4}{|c|}{ Органические вещества } & \multirow[b]{2}{*}{$\begin{array}{c}\text { Минеральные } \\
\text { вещества }\end{array}$} \\
\hline & \multicolumn{3}{|c|}{ Биоразлагаемые } & \multirow[t]{2}{*}{ Небиоразлагаемые } & \\
\hline & Растворенные & Взвешенные & Плавающие & & \\
\hline $\begin{array}{c}\text { Поступают на } \\
\text { очистку }\end{array}$ & $\begin{array}{c}\text { Углеводы, } \\
\text { белки, } \\
\text { органические } \\
\text { кислоты, } \\
\text { ионогенные } \\
\text { СПАВ }\end{array}$ & $\begin{array}{c}\text { Мицеллы белков, } \\
\text { СПАВ, } \\
\text { органоминеральных } \\
\text { веществ, клетчатка, } \\
\text { растительные и } \\
\text { животные ткани }\end{array}$ & $\begin{array}{c}\text { Пены, жиры } \\
\text { (масла), } \\
\text { легкие } \\
\text { фракции } \\
\text { растительных } \\
\text { и животных } \\
\text { тканей } \\
\end{array}$ & $\begin{array}{c}\text { Неионогенные } \\
\text { СПАВ, лигнин, } \\
\text { гуминовые } \\
\text { вещества }\end{array}$ & $\begin{array}{c}\mathrm{NO}_{3}{ }^{-}, \mathrm{Ca}^{2+}, \mathrm{K}^{+}, \\
\mathrm{NH}_{4}^{+}, \mathrm{Cl}^{-} \text {и } \\
\text { другие } \\
\text { неорганические } \\
\text { компоненты }\end{array}$ \\
\hline $\begin{array}{l}\text { Вторичные } \\
\text { загрязнения }\end{array}$ & $\begin{array}{c}\text { Вещества, } \\
\text { образуемые } \\
\text { микро- } \\
\text { организмами и } \\
\text { экстрагируемые } \\
\text { из фильтров }\end{array}$ & $\begin{array}{l}\text { Отмершие дा } \\
\text { микроорганизмы, с } \\
\text { биопленка, акт }\end{array}$ & $\begin{array}{l}\text { ожжи, } \\
\text { тработавшая } \\
\text { ивный ил }\end{array}$ & $\begin{array}{c}\text { Экстрагируемые из } \\
\text { фильтров } \\
\text { гуминовые и другие } \\
\text { органические } \\
\text { вещества }\end{array}$ & $\begin{array}{c}\text { Вещества, } \\
\text { образуемые } \\
\text { микро- } \\
\text { организмами и } \\
\text { экстрагируемые } \\
\text { из фильтров } \\
\left(\mathrm{NO}_{3}^{-}, \mathrm{NH}_{4}^{+},\right. \\
\mathrm{Ca}^{2+} \text { и др.) }\end{array}$ \\
\hline
\end{tabular}

Составлено авторами на основании офищиального источника ${ }^{7}$

${ }^{7}$ Федеральный закон "О водоснабжении и водоотведении" от 07.12.2011 N 416-ФЗ (последняя редакция). 7 декабря 2011 года N 416-Ф3. Российская федерация. (ред. от 29.07.2018). 
Таблица 4

\section{Состав органических веществ бытовых стоков}

\begin{tabular}{|l|c|c|c|c|c|}
\hline \multirow{2}{*}{ Характерная часть стока } & \multicolumn{5}{|c|}{ Массовые доли, \% } \\
\cline { 2 - 6 } & Белки & Углеводы & Жирные кислоты & Жиры, масла & Детергенты \\
\hline Сток в целом & 27,9 & 17,5 & 9,2 & 27,2 & 6,6 \\
\hline Жидкость & 28,7 & 7,7 & 7,8 & - & 13 \\
\hline Взвешенное вещество & 61 & - & - & 31 & - \\
\hline
\end{tabular}

Составлено авторами на основании официального источника ${ }^{8}$

Загрязнители, присутствующие в сточных водах как часть взвешенных частиц в воде, которая представляет собой большинство химических веществ - поток дисперсной фазы. Органические вещества из песка, глины, шлака и растительного или животного происхождения: растительный мусор, фрукты, зерно, овощи, бумага и т. д. Многие минеральные загрязнители суспендировали в воде различные минеральные соли и органические соединения, эти часть вещества, как дисперсная фаза, так и частицы воды адсорбируются на твердые частицы в динамическом равновесном состоянии, а другая часть растворяется в воде. Среди взвешенных твердых веществ среднее значение крупнодисперсного материала из общей массы загрязняющих веществ составляло 35,4 , коллоид - 14,3, a растворенное вещество - 50,3\% [3].

\section{Канцерогенные и токсичные вещества}

В первый, второй раз, канцероген присутствующий в естественной воде, добавляется к воде во время ее переработки, а в-третьих, появляется в воде, возникающей в результате ее использования: это определяется правилами вещества, безвредной химией воды.

Допустимая концентрация различных веществ в природной воде определяется по ГОСТ питьевой воды. В питьевой воде отсутствует значительная концентрация широкого спектра веществ и доступных ингредиентов. Со сточными водами сложнее. Экологический спектр веществ в сточных водах, которые на самом деле вредны для человеческого организма, достаточно широк. Однако концентрации этих веществ в бытовых сточных водах обычно небольшие, поэтому не следует превышать естественные концентрации, общие для классов качества, в 3/4 часа поверхностных вод. В данной связи отрицательное воздействие этих материалов на окружающую среду проявляется прежде всего действием практически независимого фактора «ограниченного пространства» концентрации фтора в сточных водах.

Типичными примерами вредных примесей в бытовых сточных водах являются фосфаты, азотсодержащие вещества ( $\mathrm{NH}_{4}, \mathrm{~N} 2 \mathrm{O}$ и т. д.) [4] и детергенты и могут сопровождаться фенолом и многими другими ингредиентами, перечисленными нами выше в табл. 4.

Во многих случаях токсичные сточные воды содержат ионы тяжелых металлов. Например, в европейских странах рассматриваются «предпочтительные» токсичности среди таких ионов металлов, как: $\mathrm{Sb}, \mathrm{Ba}, \mathrm{Cd}, \mathrm{Cr}, \mathrm{Cu}, \mathrm{Pb}, \mathrm{Hg}, \mathrm{Ni}, \mathrm{Se}, \mathrm{Ag}$, Th [3]. Однако анализ состава сточных вод различного происхождения показывает, что, если эта проблема присутствует, ее необходимо связать (добавить свинец из бензина) или воду из загрязненной почвы и гаража. В этой области трудно представить, что концентрация тяжелых металлов будет намного выше, чем их типичное фоновое содержание в этой области.

В сточных водах следует отметить хлоро-токсины. С одной стороны, хлор широко используется для дезинфекции питьевой воды, его обычно потребляют в чистой воде. С другой стороны, хлор является ядовитым веществом для растений или животных, так как может

\footnotetext{
${ }^{8}$ ГОСТ 27065-85 «Качество вод».
} 
обменивать различные натуральные ингредиенты, которые ингибируют эти процессы в метаболических процессах. Поэтому содержание хлора в сточных водах строго регламентировано.

Необходимо учитывать, что в связи с развитием индивидуального сельского хозяйства аграрные химические вещества, химически или биологически полученные химикаты, используемые в пестицидах, могут быть токсичны.

Следует отметить, что токсичность отдельных компонентов часто увеличивается в присутствии других веществ. Например, токсичность фенола увеличивается в результате хлорирования. Последнее приводит к производству токсичных хлорфенолов, следовые количества которых дают характерный вкус для воды до 0,1 мкг/л [4].

\section{Биологические загрязнения}

Поскольку сточные воды содержат много микроорганизмов, включая патогенные бактерии, эта вода является гигиенически опасной. В бытовых канализациях есть бактерии энтерита, патогенные бактерии дизентерии и других желудочно-кишечных заболеваний и яйца гельминтов, вторгающиеся в сточные воды с экскрементами человека и животных.

Для определения загрязнения воды патогенными бактериями проводится анализ наличия специальных бактерий в группе кишечной палочки, которая является типичным представлением кишечной флоры.

Кишечные бактерии сами по себе не являются патогенными бактериями, но они свидетельствуют о том, что вода загрязнена этими выделениями, и в результате могут существовать патогенные бактерии.

Классификация загрязненности водных объектов по гидробиологическим и микробиологическим показателям приведена в табл. 5.

Таблица 5

Классификация загрязненности водных объектов по гидробиологическим и микробиологическим показателям

\begin{tabular}{|c|c|c|c|}
\hline \multirow{3}{*}{$\begin{array}{c}\text { Уровень } \\
\text { загрязненности }\end{array}$} & \multicolumn{3}{|c|}{ Гидробиологические показатели } \\
\hline & \multirow{2}{*}{$\begin{array}{c}\text { По фитопланктону, } \\
\text { зоопланктону, } \\
\text { перифитону (индекс } \\
\text { сапробности) }\end{array}$} & \multicolumn{2}{|c|}{ По зообентосу } \\
\hline & & $\begin{array}{c}\text { Отношение общей численности } \\
\text { олигохет к общей численности } \\
\text { донных организмов, \% }\end{array}$ & $\begin{array}{c}\text { биотический индекс по } \\
\text { Вудивусу, баллы }\end{array}$ \\
\hline Очень чистые & $<1,0$ & $1-20$ & 10 \\
\hline Чистые & $1,0-1,5$ & $21-35$ & $7-9$ \\
\hline $\begin{array}{c}\text { Умеренно } \\
\text { загрязненные }\end{array}$ & $1,5-2,5$ & $36-50$ & $5-6$ \\
\hline Загрязненные & $2.5-3,5$ & $51-65$ & 4 \\
\hline Грязные & $3,5-4.0$ & $66-85$ & $2-3$ \\
\hline Очень грязные & $>4$ & $86-100$ & $0-1$ \\
\hline \multirow[b]{2}{*}{$\begin{array}{c}\text { Уровень } \\
\text { загрязненности }\end{array}$} & \multicolumn{3}{|c|}{ Микробиологические показатели } \\
\hline & $\begin{array}{c}\text { Общее количество } \\
\text { бактерий, млн кл/см³ }\end{array}$ & 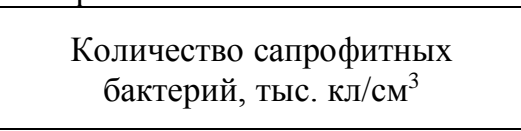 & $\begin{array}{c}\text { Отношение общего } \\
\text { кол-ва бактерий к кол-ву } \\
\text { сапрофитных бактерий } \\
\end{array}$ \\
\hline Очень чистые & $<0,5$ & $<0,5$ & 10 \\
\hline Чистые & 0,5 & $0,5-5,0$ & $<10$ \\
\hline $\begin{array}{c}\text { Умеренно } \\
\text { загрязненные }\end{array}$ & $1,1-3,0$ & $5,1-10,0$ & 10 \\
\hline Загрязненные & $3,1-5,0$ & $10,1-50,0$ & $<100$ \\
\hline Грязные & $5,1-10,0$ & $50,01-100,0$ & $<100$ \\
\hline
\end{tabular}




\begin{tabular}{|c|c|c|c|}
\hline \multirow{2}{*}{$\begin{array}{c}\text { Уровень } \\
\text { загрязненности }\end{array}$} & $\begin{array}{c}\text { По фитопланктону, } \\
\text { зоопланктону, } \\
\text { перифитону (индекс } \\
\text { сапробности) }\end{array}$ & $\begin{array}{c}\text { Отношение общей численности } \\
\text { олигохет к общей численности } \\
\text { донных организмов, \% }\end{array}$ & $\begin{array}{c}\text { биотический индекс по } \\
\text { Вудивусу, баллы }\end{array}$ \\
\hline Очень грязные & $>10,0$ & $>100,0$ & $<100$ \\
\hline
\end{tabular}

Составлено авторами на основании офищиального источника ${ }^{9}$

Основной причиной биологического загрязнения является сброс из дождевой воды, из организма человека, домашнего скота, мытья тела, одежды и других предметов домашнего обихода и др. Ежедневно в сточных водах присутствуют миллиарды организмов. Многие из микроорганизмов попадают в сточные воды либо путем отходов пищи, либо отходов туалета. Обычными классами микроорганизмов являются бактерии и вирусы.

Бактерии в основном состоят из одноклеточных организмов с клеточными стенками и примитивными ядрами. Бактериальные клетки состоят из тех же биологических и микроэлементов, которые определяют состав дезоксирибонуклеиновой кислоты (ДНК) и более высоких тканей растений и животных. Бактерии вовлечены в материальную циркуляцию в природе. Поэтому они существуют повсюду в почве, почве, воздухе, воде, живых растениях и растительных существах. Принципиальная схема круговорота органического углерода и азота приведена на рис. 6 [5].

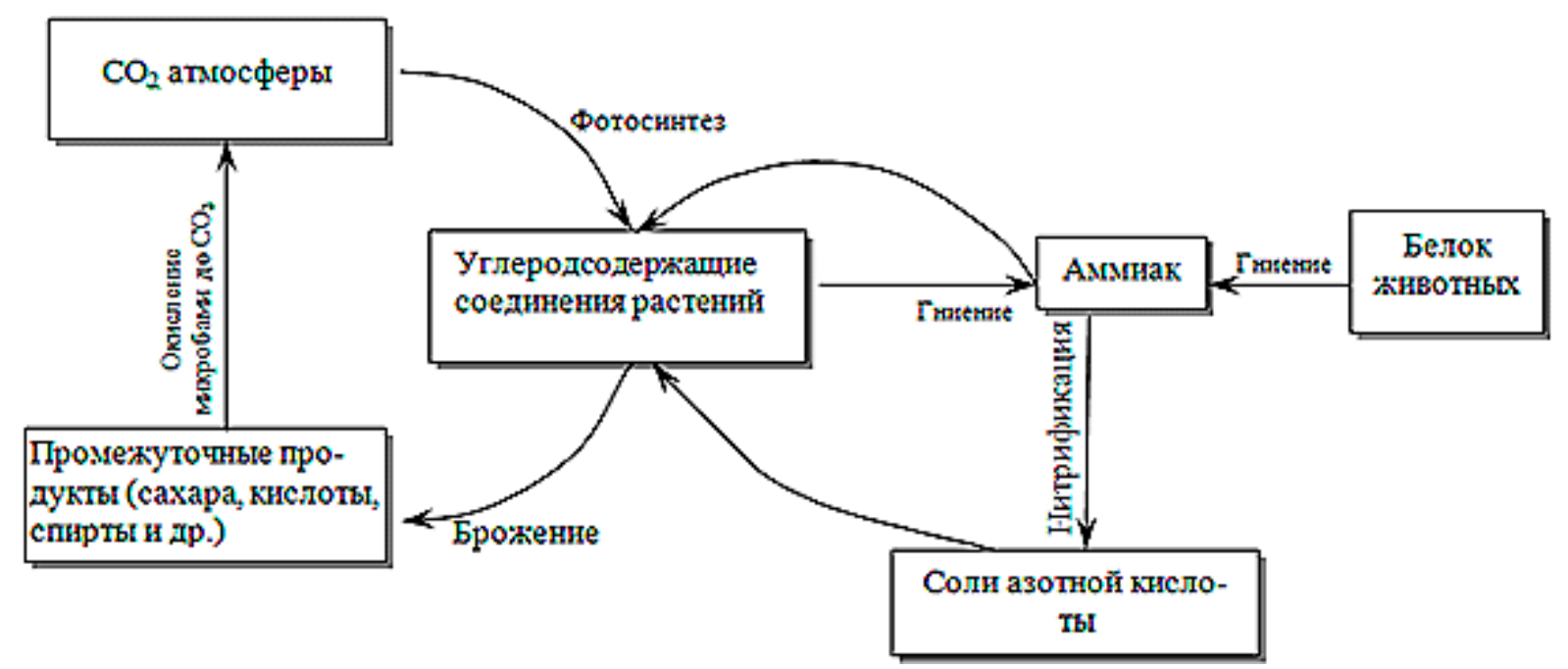

Рисунок 6. Схема биогенныхх ичиклов круговорота в природе органического углерода и азота [5]

Большинство бактерий имеют форму стержней, но они также являются сферическими, нитевидными и другими формами. Сферические бактерии часто называют кокками. Когда сферические бактерии спарены, они диплоидны. Если они связаны друг с другом, их называют стрептококками. Среди бактерий выделяются аэробные бактерии и анаэробные бактерии. Первый из процессов важных видов деятельности потребляет кислород, последний не потребляет кислород. В неблагоприятных условиях некоторые бактерии образуют споры, особые образования, обеспечивающие устойчивость бактерии к внешним воздействиям.

Наиболее распространенные виды патогенных бактерий и вирусов, а также их основные характеристики приведены в табл. 6 и 7.

\footnotetext{
${ }^{9}$ Методические указания по разработке нормативов предельно допустимых сбросов вредных веществ в поверхностные водные объекты.
} 
Таблица 6

\section{Характеристика основных патогенных бактерий, населяющих бытовые воды и отходы продуктов питания}

\begin{tabular}{|c|c|c|}
\hline Бактерии & Описание & Профилактические меры \\
\hline Сальмонеллы & $\begin{array}{l}\text { Грамположительные палочки длиной } 2-3 \text { мкм и } \\
\text { шириной до } 0,6 \text { мкм. } \mathrm{T}_{\text {опт. }}=37{ }^{0} \mathrm{C}^{*} . \text { Размножаются при } \\
\text { 5-45 }{ }^{0} \mathrm{C} \text {. Вызывают брюшной тиф, гастроэнтерит. }\end{array}$ & $\begin{array}{l}\text { Гибнут при } 75{ }^{0} \mathrm{C} \text { через } 5 \text { мин и } \\
\text { мгновенно при кипячении. }\end{array}$ \\
\hline Эшерихии & $\begin{array}{l}\text { Имеются патогенные штаммы кишечной палочки с } \\
\text { размерами } 1,1-1,5 \text { х 2,0-6,0 мкм. Существуют } \\
\text { подвижные и лишенные жгутиков организмы. } \\
\mathrm{T}_{\text {опт. }}=37^{0} \mathrm{C} \text {. Вызывают заболевания желудка. }\end{array}$ & $\begin{array}{l}\text { Приспособились к существованию в } \\
\text { организме человека. Погибают при } \\
\text { кипячении. }\end{array}$ \\
\hline Шигеллы & Возбудители дизентерии. & $\begin{array}{l}\text { Переносят замораживание до } \\
\text { месяца. В сточных водах живут до } \\
\text { недели. }\end{array}$ \\
\hline Энторокорки & $\begin{array}{l}\text { Размножаются при } 10-15^{0} \mathrm{C} . \text { Устойчивы к высыханию и } \\
\text { действию низких температур. }\end{array}$ & $\begin{array}{l}\text { Выдерживают нагревание до } 85{ }^{0} \mathrm{C} \text { в } \\
\text { течение } 10 \text { мин. }\end{array}$ \\
\hline Ботулина & $\begin{array}{l}\text { Спорообразующая анаэробная палочка. } \mathrm{T}_{\text {опт. }}=20-37{ }^{0} \mathrm{C} \text {. } \\
\text { В виде спор присутствует даже в засоленных почвах. } \\
\text { Размножение прекращается при рН 4,4 и } 10-12{ }^{0} \mathrm{C} \text {. } \\
\text { Вырабатывают токсин вызывающий ботулиз. }\end{array}$ & $\begin{array}{l}\text { Выдерживают нагревание до } 120{ }^{\circ} \mathrm{C} \\
\text { в течение } 10 \text { мин. } \\
\text { Погибают при длительном } \\
\text { кипячении. }\end{array}$ \\
\hline
\end{tabular}

Составлено авторами на основании источника [2]

Таблица 7

Руководство по контролю качества питьевой воды

\begin{tabular}{|l|l|}
\hline \multicolumn{1}{|c|}{ Вирусы } & \multicolumn{1}{c|}{ Описание } \\
\hline Вирусы полиомелита & КС 3*** (паралич, менингит, лихорадка) \\
\hline Эховирусы & КС 32 (респиараторные заболевания, менингит, лихорадка, сыпь, гастроэнтерит) \\
\hline Коксавирусы А1-22.24 & КС 23 (кишечные заболевания, менингит, заболевание дыхательных путей и др.) \\
\hline Коксавирусы В1-6 & КС 6 (сердечные и респираторные заболевания) \\
\hline Кишечные вирусы 68-71 & КС 4 (кишечные и респираторные заболевания, сыпь) \\
\hline Вирус гепатита А & Наиболее устойчив \\
\hline Аденовирусы & КС 41 (респираторные заболевания, конъюнктивит, диарея) \\
\hline Калицивирусы & КС 5 (гастроэнтерит) \\
\hline Сферические вирусы & КС 14. В том числе гастроэнтерит \\
\hline Вирус гепатита Е & Вызывает гепатит в поясах тропического и субтропического климата \\
\hline Астровирусы & Малоизученные вирусы, вызывающие гастроэнтерит \\
\hline Составлено
\end{tabular}
Составлено авторами на основании ряда источников $\left[2,6,{ }^{10}\right]$

Вирусы, такие как бактерии, имеют серьезный риск передачи инфекций через воду. Вирус содержит в структуре и составе соответствующие соединения нуклеиновой кислоты. Практически все вирусы проходят через бактериальные фильтры. Зрелые вирусные частицы часто называют вирионами. Вирионы и их споры имеют более высокую устойчивость к неблагоприятным условиям по сравнению с бактериями. В большинстве случаев вокруг вирусных частиц образуется оболочка защитного белка. Вирус растет только в клеткаххозяевах. Наибольший риск представляет вирус, реплицирующийся в кишечнике человека. Основными векторами вирусов являются млекопитающие и часто являются людьми. Это связано с тем, что в сточных водах домохозяйства образуется сильный вирусный поток. Не исключено и перемещение вируса почвенными нематодами. Термическая обработка и некоторые меры по дезинфекции воды считаются наиболее эффективным способом уничтожения вируса. Важнейшие семейства патогенных для человека вирусов, которые могут встречаться в загрязненной воде, и вызываемые ими заболевания, приведены в табл. 7.

${ }^{10}$ ГОСТ 12.3.006-75 ССБТ. Эксплуатация водопроводных и канализационных сооружений и сетей. Общие требования безопасности. 
У каждого вида вирусов есть собственная микробная среда обитания («экологический статус»), с которой они живут, размножаются и существуют в виде спор в огромном наборе мест обитания. Это обусловливает удивительное разнообразие микробных видов и классов. Поэтому эффективный метод дезактивации должен быть направлен, прежде всего, на удаление бактериальных спор.

Среди естественных факторов, определяющих выживаемость микроорганизмов, обычно выделяют температуру, люминесценцию и звуковые эффекты.

Анализ данных, опубликованных в научной литературе, показывает, что при дезактивации для большинства микроорганизмов повышают температуру до примерно $85{ }^{\circ} \mathrm{C}$ в течение 15-30 минут. На это же указывают и официальные источники ${ }^{11}$. Хотя при кипячении с обратным холодильником от 3 до 5 минут при $100{ }^{0} \mathrm{C}$ приводит к тому, что большинство микроорганизмов погибает почти мгновенно. Споры отдельных микробных видов могут продолжать жить при кипячении от нескольких минут до нескольких часов.

Свет и звук также влияют на микроорганизмы. Считается, что при воздействии УВЧ и нагреве до $100{ }^{\circ} \mathrm{C}$ происходит наиболее эффективное разрушение микрофлоры.

Экстремальное разнообразие микроорганизмов и простейших, обнаруженных в бактериологическом анализе, затрудняет поиск сточных вод в муниципалитетах на основе конкретных тестов на конкретные патогены. Поэтому в текущем микробиологическом анализе оценивается, как правило, только наличие индикаторных организмов. Примером такого микроорганизма является Escherichiacoli. Она всегда живет в кишечнике людей и скота. Тем не менее, это предпочтительнее с точки зрения выживаемости среды Escherichiacoli, сопоставимой с другими патогенными бактериями. Поэтому присутствие бактерий Escherichacoli свидетельствует о фекальном загрязнении присутствия сточных вод и, следовательно, других патогенах кишечных инфекций.

C положительным результатом текущего анализа проводятся комплексные исследования по нескольким биологическим параметрам и отдельным типам микроорганизмов. Важнейшими показателями текущего микробиологического анализа, которые рекомендуются для использования с различными стандартами, показаны в табл. 9.

Таблица 9

Показатели микробиологического анализа питьевой воды по принятым стандартам

\begin{tabular}{|l|c|c|c|c|c|}
\hline \multicolumn{1}{|c|}{ Показатель } & Ед. измерения & ЕС- & U.S.EРА & ВО3 & СанПиН \\
\hline Общее микробное число & СFU- & $\begin{array}{c}\left.10 \text { (при } 22^{0} \mathrm{C}\right) \\
\left.100 \text { (при } 37{ }^{0} \mathrm{C}\right)\end{array}$ & 500 & - & 50 \\
\hline Общие колиформные бактерии & кол-во в 100 мл & Отсутствие & $5 \%$ & Отсутствие & Отсутствие \\
\hline $\begin{array}{l}\text { Термотолерантныеколиформные } \\
\text { бактерии }\end{array}$ & кол-во в 100 мл & Отсутствие & - & Отсутствие & Отсутствие \\
\hline Фекальные стрептококки & кол-во в 100 мл & Отсутствие & - & - & - \\
\hline Колифаги & БОЕ - 100 мл & - & - & - & Отсутствие \\
\hline Споры клостридий & В 20 мл & $<1$ & - & - & Отсутствие \\
\hline Цисты лямблий & В 50 мл & - & Отсутствие & - & Отсутствие \\
\hline
\end{tabular}

Составлено авторами на основании источников $\left[2,6,{ }^{12}\right]$

\section{Отработанные растворы моющих средств}

\footnotetext{
${ }^{11}$ Методические указания по разработке нормативов предельно допустимых сбросов вредных веществ в поверхностные водные объекты.

${ }^{12}$ ГОСТ 27065-85 «Качество вод».
} 
Основой этих растворов являются поверхностно-активные вещества (ПАВ), такие как: мыло, моющее средство (моющее средство, шампунь). Мыло производится из животных или растительных жиров и масел, и синтетических моющих средств (детергентов), полученных из нефтепродуктов или других натуральных ингредиентов. В принципе, поверхностно-активное вещество представляет собой анионное поверхностно-активное вещество, принадлежащее классу полуколлоидов. Молекулы этих веществ содержат около 10-18 атомов углерода. В разбавленном растворе полуколлоид существует как отдельная молекула, а в концентрированном растворе он связан с мицеллой. Мицеллы могут быть в сферической или столбчатой форме с массой и размерами, соответствующими параметрам коллоидных частиц, в зависимости от концентрации поверхностно-активного вещества. Семикоидные мицеллы могут растворять частицы загрязнителей. В то же время их объем будет увеличиваться. Этот эффект, называемый солюбилизацией ${ }^{13}$, существует с другими явлениями, основанными на очищающем действии мыла. Таким образом, значительная часть раствора детергента для отходов содержит мицеллы, которые являются примесями.

Поскольку нормальное мыло не представляет реальной опасности для окружающей среды - состоит из карбоновой кислоты и алкилсульфата с разветвленной цепью, то стабилизация загрязняющих частиц в моющих композициях часто вводится с полифосфатом натрия, который взаимодействует с минеральными компонентами отходов и образует плохо водорастворимую соль ортофосфорной кислоты. Пенообразующим моющим средством часто добавляют неионогенный ПАВ типа $\mathrm{RCO}\left(\mathrm{OCH}_{2} \mathrm{CH}_{2}\right) \mathrm{m} \mathrm{CH}_{2} \mathrm{CH}_{2} \mathrm{OH}$ для уменьшения поверхностно-активного вещества моющего средства. Однако, поскольку токсичность этих вод связана с присутствием этих веществ, представляется очевидным, что загрязняющие водные моющие средства нуждаются в следующей дезинфекции в качестве физической обработки поверхностно-активными веществами.

Средства для защиты и кондиционирования, медицинские и тонизирующие средства для кожи, гидротропы, сорастворители, фунгициды, антиоксиданты, пигменты, хелатирующие агенты, неорганические соли и парфюмерия содержатся в ПАВ (табл. 10).

Таблица 10

Примерные концентрации (\% по массе) отдельных веществ в составе СМС

\begin{tabular}{|c|c|c|c|}
\hline Компоненты & $\begin{array}{c}\text { Порошкообразные } \\
\text { СМС }\end{array}$ & $\begin{array}{c}\text { Жидкие } \\
\text { СМС }\end{array}$ & Назначение \\
\hline ПАВ (всего) & $15-18$ & $24-35$ & \multirow{6}{*}{$\begin{array}{l}\text { Основные реагенты стирки } \\
\text { Регулирование пенообразования }\end{array}$} \\
\hline алкилбензолсульфонаты & 4-18 & $8-15$ & \\
\hline алкилсульфаты & $0-12$ & $0-6$ & \\
\hline алкилсульфонаты & - & $0-13$ & \\
\hline мыло & $0-15$ & - & \\
\hline Неионогенные ПАВ & $0-5$ & $3-30$ & \\
\hline Триполифосфат натрия & $35-40$ & - & \multirow{2}{*}{$\begin{array}{l}\text { Связывают поливалентные } \\
\text { катионы в комплексы }\end{array}$} \\
\hline Триполифосфат калия & - & 3,5 & \\
\hline $\mathrm{Na}_{2} \mathrm{SiO}_{3}$ & $3-8$ & & \multirow{2}{*}{$\begin{array}{l}\text { Обеспечивают оптимальное } \\
\text { значения рН раствора СМС }\end{array}$} \\
\hline $\mathrm{Na}_{2} \mathrm{CO}_{3}$ & $10-20$ & & \\
\hline $\begin{array}{ll}\text { Отбеливатели } & \text { химические } \\
\text { пероксоборат натрия } & \end{array}$ & $8-15$ & - & \multirow[t]{2}{*}{ Отбеливают ткани } \\
\hline Отбеливатели оптические & $0,2-0,3$ & 0,1 & \\
\hline $\begin{array}{l}\text { Антиресорбент } \\
\text { карбоксилметилцеллюлоз }\end{array}$ & $0,9-12$ & - & $\begin{array}{l}\text { Предотвращают } \\
\text { загрязнения }\end{array}$ \\
\hline
\end{tabular}

${ }^{13}$ Солюбилиза́ция (от лат. solubilis - «растворимый») - коллоидный процесс, самопроизвольного и обратимого проникновения солюбилизата - вещества с низкой молекулярной массой (как правило неполярного (гидрофобного)) внутрь мицелл солюбилизатора - поверхностно-активного вещества или высокомолекулярных глобул (клубков) полимера. Источник: https://www.yandex.ru/search/?text. 


\begin{tabular}{|l|c|c|c|}
\hline \multicolumn{1}{|c|}{ Компоненты } & $\begin{array}{c}\text { Порошкообразные } \\
\text { СМС }\end{array}$ & $\begin{array}{c}\text { Жидкие } \\
\text { СМС }\end{array}$ & \multicolumn{1}{c|}{ Назначение } \\
\hline Фермент (протеаза) & 0,2 & - & Ускоряют расщепление жиров \\
\hline Стабилизаторы & $0-0,3$ & - & \\
\hline Парфюмерные отдушки & $0-0,2$ & 0,1 & \\
\hline $\mathrm{Na}_{2} \mathrm{SO}_{4}$, и вода & До 10 & - & \\
\hline
\end{tabular}

Составлено авторами на основании источника [6]

Как видно из табл. 10, основой моющих средств является ПАВ (поверхностно-активное вещество). Чистящий порошок также содержит большое количество комплексообразователя на основе триполифосфата натрия. ПАВ производятся не только из натуральных и рыбных масел или из неэфирных растительных масел, но также из синтетических продуктов (нефтяной парафин, этилен, пропилен, олефины с длинной цепью).

Часто моющая композиция включает в себя выбор нескольких синергистов ПАВ, которые усиливают действие моющих средств отдельных компонентов в смеси. Количество различных типов поверхностно-активных веществ в порошке может достигать $35 \%$.

В зависимости от природы полярной группы и способности молекулы ПАВ диссоциировать на ионы, они различаются следующим образом: неионные, ионогенные и амфотерные ПАВ. Основные классы ПАВ и их специфичные характеристики приведены в табл. 11.

\section{Классификация ПАВ}

Таблица 11

\begin{tabular}{|c|c|c|}
\hline Класс ПАВ & Специфичные особенности & Примеры \\
\hline Неионогенные & $\begin{array}{l}\text { Не диссоциируют в воде. Жидкое состояние и } \\
\text { небольшое пенообразование в водных растворах. } \\
\text { Растворимость связана с наличием в молекулах } \\
\text { гидрофильных эфирных и гидроксильных групп. }\end{array}$ & Оксиэтилированные спирты \\
\hline Катионные & $\begin{array}{l}\text { Диссоциируют на катион с длинной гидрофобной } \\
\text { цепью и анион минеральной кислоты. }\end{array}$ & Соли алифатических кислот - мыла \\
\hline Анионные & $\begin{array}{l}\text { диссоциируют на анион с длинной гидрофобной цепью } \\
\text { и катион. }\end{array}$ & \\
\hline Амфолиты & $\begin{array}{l}\text { Как правило, содержат в молекуле одну или несколько } \\
\text { основных и кислотных групп, неионогенную } \\
\text { полигликолевую группу. }\end{array}$ & $\begin{array}{l}\text { Вода, спирты }(\mathrm{ROH}), \text { кислые и } \\
\text { основные соли }\left(\mathrm{NaHCO}_{3}, \mathrm{AlOHCl}_{2}\right) \text {, } \\
\text { анионы } \mathrm{HCO}_{3-}, \mathrm{HPO}_{42-}, \mathrm{H}_{2} \mathrm{PO}_{4-}\end{array}$ \\
\hline
\end{tabular}

Составлено авторами на основании источника [7]

Коллоидная химия неионогенного ПАВ изменяется в зависимости от длины как гидрофильной полигликолевой цепочки, так и гидрофобной группы. Неионогенные поверхностно-активные вещества хорошо смешиваются с ионными поверхностно-активными веществами и часто включаются в детергенты для оптимизации вспенивания.

Ионогенные ПАВ представляют собой вещества, способные к диссоциации молекул в данном растворителе с образованием ионов.

Поверхностная активность начинает проявляться с длиной гидрофобной цепи, что соответствует 8 атомам углерода, а растворимость в воде теряется по мере увеличения длины цепи. Длина углеводородной гидрофобной цепи зависит от характера функционального промежуточного продукта и от гидрофильности полярной части молекулы и обычно достигает $\mathrm{C}_{18}$.

В принципе, поверхностно-активное вещество представляет собой анионное ПАВ, принадлежащее классу полуколлоидов. Молекулы этих веществ содержат около 10-18 атомов углерода. В разбавленном растворе полуколлоид существует как отдельная молекула и связан с мицеллой в концентрированном растворе. Состав мицелл может содержать десятки молекул 
поверхностно-активного вещества. Мицеллы могут быть сферическими или столбчатыми структурами с массами и размерами, соответствующими параметрам коллоидных частиц, в зависимости от концентрации раствора поверхностно-активного вещества. Полуколлоидные мицеллы могут наносить частицы загрязнителей. В то же время их объем будет увеличиваться. Этот эффект, как мы отмечали выше, называется солюбилизацией и сосуществует с другими явлениями, основанными на механизме действия поверхностно-активного вещества. Таким образом, значительная часть раствора детергента для отходов содержит мицеллы, которые являются примесями.

Поверхностно-активное вещество, имеющее алкильную цепь $\mathrm{C}_{12}-\mathrm{C}_{14}$, обычно имеет оптимальное детергентное действие при $25-35{ }^{0} \mathrm{C}$ [1]. По мере повышения температуры оптимальные значения наблюдаются в гомологах ${ }^{14} \mathrm{C}_{14}-\mathrm{C}_{16}$.

Обычные мыла, приготовленные на основе карбоновых кислот с неразветвленными цепями и солями алкилсульфатов, легко разлагаются и, следовательно, не представляют реальной опасности для окружающей среды. Чтобы стабилизировать загрязняющие частицы, полифосфат натрия вводится в состав моющего средства, который часто взаимодействует с минеральным компонентом выходящего потока и образует плохо водорастворимую соль ортофосфорной кислоты.

Оптимальное детергентное действие при $25-35{ }^{0} \mathrm{C}$ обычно является поверхностноактивным веществом с $\mathrm{C}_{12}-\mathrm{C}_{14}$ - алкильными цепями. По мере повышения температуры оптимальные значения наблюдаются в гомологах $\mathrm{C}_{14}-\mathrm{C}_{16}$.

Часто моющие композиции, содержащие несколько синергистов ПАВ, которые усиливают детергентный эффект в смеси, включены в моющие композиции. Количество различных типов ПАВ в порошке составляет до $35 \%$.

\section{Ливневые стоки}

Дождевая вода - это поверхностная вода, образующаяся в результате дождя или таяния снега. Количество дождевой воды сильно зависит от осадков. Даже кратковременные дожди могут привести к значительному количеству воды и вызвать наводнение низменностей и эрозии почв.

Сама по себе дождевая вода содержит очень небольшое количество растворенных веществ. В принципе, это случайные компоненты, входящие в атмосферу с выгрузкой газа из крупных заводов, фабрик или тепловых электростанций.

В то же время относительно чистая дождевая вода поднимается на землю и загрязняется. Прикрепляется к поверхности земли, крыше дома или другим объектам для растворения или перемещения значительного количества загрязняющих веществ в коллоидном дисперсионном состоянии. Химический состав дождевой воды приведен в табл. 12.

${ }^{14}$ Гомологи - это вещества, которые имеют разный состав, но схожие строение и свойства // Источник: https://www.yandex.ru/search/?text=\%D0\%B3\%D0\%BE\%D0\%BC\%D0\%BE\%D0\%BB\%D0\%BE\%D0\%B3\&lr=54. 
Таблица 12

\section{Состав органических веществ ливневых стоков}

\begin{tabular}{|l|c|c|c|c|c|}
\hline \multirow{2}{*}{ Характерная часть стока } & \multicolumn{5}{|c|}{ Массовые доли, \% } \\
\cline { 2 - 6 } & Белки & Углеводы & Жирные кислоты & Жиры (масла) & Детергенты \\
\hline Сток в целом & 27,9 & 17,5 & 9,2 & 27,2 & 6,6 \\
\hline Жидкость & 28,7 & 7,7 & 7,8 & - & 13 \\
\hline Взвешенное вещество & 61 & - & - & 31 & - \\
\hline
\end{tabular}

Составлено авторами на основании официального источника ${ }^{15}$

Как видно из табл. 12, дисперсные вещества составляют основу дождевой воды. К настоящему времени многими исследованиями убедительно показано, что большинство загрязняющих веществ адсорбируются частицами дисперсной фазы. Среди загрязняющих веществ в дождевой воде присутствуют тяжелые металлы, токсичные, нетоксичные органические вещества и микроорганизмы [8]. Источниками этих загрязняющих веществ являются «человеческие разобранные горы», такие как промышленные отходы газа в атмосферу, дымовые газы, отходы птиц, домашний скот, строительные и бытовые мусора [9]. В конце концов, дождевая вода, текущая на земле, еще более токсична, чем утечка из септика.

\section{Состояние очистной системы Свердловской области}

В проекте Государственного доклада по Свердловской области [16] отмечается, что в 2017 г. на территории Свердловской области отведение сточных вод в поверхностные водные объекты осуществляли 286 водопользователей. Из них большинство (218) водопользователей эксплуатировали 327 комплексов очистных сооружений с последующим сбросом очищенных вод в поверхностные водные объекты проектной мощностью 1592,41 млн куб. м/год, что на 18,17 млн куб. м/год (1,1 \%) меньше, чем в 2016 г. Фактический объем сточных вод, поступивших на очистку в 2017 г., составил 611,29 млн куб. м. (табл. 13).

Таблица 13

\section{Характеристика очистных сооружений Свердловской области в 2017 г. [16, с. 36-36]}

\begin{tabular}{|c|c|c|c|c|}
\hline \multirow{2}{*}{$\begin{array}{l}\text { Номер } \\
\text { строки }\end{array}$} & \multirow[b]{2}{*}{ Очистные сооружения } & \multicolumn{2}{|c|}{ Бассейн рек } & \multirow{2}{*}{$\begin{array}{l}\text { Итого по } \\
\text { Свердловской } \\
\text { области }\end{array}$} \\
\hline & & Объ & Волга & \\
\hline 1 & 2 & 3 & 4 & 5 \\
\hline 1 & Общее количество, всего, в том числе & 287 & 40 & 327 \\
\hline 2 & биологической очистки & 132 & 23 & 155 \\
\hline 3 & физико-химической очистки & 39 & 5 & 44 \\
\hline 4 & механической очистки & 116 & 12 & 128 \\
\hline 5 & $\begin{array}{l}\text { Проектная мощность очистных сооружений (млн куб. м/год), } \\
\text { всего, в том числе }\end{array}$ & 1491,7 & 100,7 & 1592,4 \\
\hline 6 & биологической очистки & 677,4 & 75,2 & 752,6 \\
\hline 7 & физико-химической очистки & 126,5 & 11,2 & 137,7 \\
\hline 8 & механической очистки & 687,8 & 14,3 & 702,1 \\
\hline 9 & $\begin{array}{l}\text { Фактическое поступление сточных вод в поверхностные } \\
\text { водные объекты после очистных сооружений (млн куб. } \\
\text { м/год), всего, в том числе }\end{array}$ & 557,42 & 53,78 & 611,2 \\
\hline 10 & биологической очистки & 325,98 & 39,1 & 365,08 \\
\hline 11 & физико-химической очистки & 89,6 & 8,32 & 97,92 \\
\hline 12 & механической очистки & 141,84 & 6,36 & 148,2 \\
\hline 13 & $\begin{array}{l}\text { Количество очистных сооружений, обеспечивающих } \\
\text { нормативную очистку, всего, в том числе }\end{array}$ & 73 & 14 & 87 \\
\hline
\end{tabular}

${ }^{15}$ ГОСТ 27065-85 «Качество вод». 


\begin{tabular}{|c|c|c|c|c|}
\hline \multirow{2}{*}{$\begin{array}{l}\text { Номер } \\
\text { строки }\end{array}$} & \multirow[b]{2}{*}{ Очистные сооружения } & \multicolumn{2}{|c|}{ Бассейн рек } & \multirow{2}{*}{$\begin{array}{c}\text { Итого по } \\
\text { Свердловской } \\
\text { области } \\
\end{array}$} \\
\hline & & Обь & Волга & \\
\hline 1 & 2 & 3 & 4 & 5 \\
\hline 14 & биологической очистки & 18 & 6 & 24 \\
\hline 15 & физико-химической очистки & 20 & 2 & 22 \\
\hline 16 & механической очистки & 35 & 6 & 41 \\
\hline 17 & $\begin{array}{l}\text { Проектная мощность очистных сооружений, } \\
\text { обеспечивающих нормативную очистку (млн куб. м/год), } \\
\text { всего, в том числе }\end{array}$ & 85,67 & 11,13 & 96,8 \\
\hline 18 & биологической очистки & 1,38 & 2,35 & 3,73 \\
\hline 19 & физико-химической очистки & 65,29 & 0,09 & 65,38 \\
\hline 20 & механической очистки & 19,00 & 8,69 & 27,69 \\
\hline 21 & $\begin{array}{l}\text { Фактический сброс нормативно-очищенных сточных вод в } \\
\text { поверхностные водные объекты (млн куб. м/год) всего, в том } \\
\text { числе }\end{array}$ & 66,08 & 5,22 & 71,30 \\
\hline 22 & биологической очистки & 0,68 & 0,44 & 0,98 \\
\hline 23 & физико-химической очистки & 54,54 & 0,08 & 54,62 \\
\hline 24 & механической очистки & 10,86 & 4,70 & 15,70 \\
\hline
\end{tabular}

В Свердловской области нормативную очистку сточных вод обеспечивают 87 комплексов очистных сооружений (27\% от общего числа очистных сооружений), в том числе 73 очистных сооружения по бассейну р. Оби, 14 - по бассейну р. Волги. Очевидно, что этого количества недостаточно.

Также остро стоит проблема с отводом с городской территории Свердловской области ливневых стоков и их дальнейшей очисткой перед сбросом в водные объекты. Необходимо подчеркнуть, что отсутствие на текущий момент очистных сооружений ливневого стока с территории жилой застройки региона приводит к сбросу в водные объекты большого количества загрязненных сточных вод, содержащих взвешенные вещества, нефтепродукты, железо, сульфаты и др. [16].

Как отмечают многие специалисты $[14,15,16]$ основными причинами невыполнения нормативов работы очистных сооружений в Свердловской области, да и в РФ в целом, можно отнести следующие основные факторы:

- Физический износ оборудования, неудовлетворительное техническое состояние очистных сооружений.

- Несоответствие состава поступающих сточных вод и систем очистки.

- $\quad$ Отсутствие сооружений по доочистке сточных вод.

• $\quad$ Недогруз по гидравлике и неравномерная подача сточных вод.

- Нарушение технико-технологических режимов эксплуатации очистных сооружений ${ }^{16}$.

- Несвоевременное проведение ремонтных и реставрационных работ, замены вышедших из строя оборудования, узлов и деталей.

- Отсутствие достаточного финансирования отрасли, финансирование по «остаточному принципу».

${ }^{16}$ В том числе - поступление в сети хозяйственно-бытовой канализации и на сооружения биологической очистки производственных сточных вод с высокими концентрациями металлов без предварительной локальной очистки. 
- Нехватка высококвалифицированных кадров для осуществления грамотной эксплуатации очистных сооружений.

- $\quad$ и др.

В целях улучшения качества сбрасываемых сточных вод, уменьшения их влияния на водные объекты, сокращения объёма выброса стоков необходимы следующие первоочередные меры:

- $\quad$ строительство новых, реконструкция и расширение действующих очистных сооружений;

- $\quad$ строительство локальных очистных сооружений, блоков доочистки;

- $\quad$ ввод в эксплуатацию систем оборотного и повторного водоснабжения;

- $\quad$ выявление дополнительных источников финансирования системы очистных сооружений, в том числе - за счёт концессионных соглашений, создания частногосударственных партнёрств;

- $\quad$ формирование «государственного заказа» и выделения целевых бюджетных мест в колледжах и вузах на обучение по специальностям, связанным с ЖКХ, водопотреблением и водоотведением.

\section{Выводы}

1. Проведён анализ систем ливневой и бытовой канализации на основе исследования некоторых технических, организационных и экономических аспектов деятельности систем. Показано, что на текущий момент проблема очистки сточных вод чрезвычайно актуальна. Установлено, что многие компании сбрасывают большое количество сточных вод, которые фактически не обрабатываются в местных водохранилищах.

2. Выявлено, что в исследуемой сфере в РФ в целом и в Свердловской области, в частности, наблюдается невыполнение нормативов работы очистных сооружений. Ключевыми причинами данной ситуации являются следующие основные факторы:

1. физический износ оборудования, неудовлетворительное техническое состояние очистных сооружений;

2. несоответствие состава поступающих сточных вод и систем очистки;

3. отсутствие сооружений по доочистке сточных вод;

4. недогруз по гидравлике и неравномерная подача сточных вод;

5. нарушение технико-технологических режимов эксплуатации очистных сооружений;

6. несвоевременное проведение ремонтных и реставрационных работ, замены вышедших из строя оборудования, узлов и деталей;

7. отсутствие достаточного финансирования отрасли, финансирование по «остаточному принципу»;

8. нехватка высококвалифицированных кадров для осуществления грамотной эксплуатации очистных сооружений;

9. и др. 
3. Авторы полагают, что в целях улучшения качества сбрасываемых сточных вод, уменьшения их влияния на водные объекты, сокращения объёма выброса стоков необходимы следующие первоочередные меры:

а) строительство новых, реконструкция и расширение действующих очистных сооружений;

б) строительство локальных очистных сооружений, блоков доочистки;

в) ввод в эксплуатацию систем оборотного и повторного водоснабжения;

г) выявление дополнительных источников финансирования системы очистных сооружений, в том числе - за счёт концессионных соглашений, создания частногосударственных партнёрств;

д) формирование «государственного заказа» и выделения целевых бюджетных мест в колледжах и вузах на обучение по специальностям, связанным с ЖКХ, водопотреблением и водоотведением.

\section{ЛИТЕРАТУРА}

1. Ветошкин А.Г. «Инженерная защита гидросферы от сбросов сточных вод» 2016 г.

2. Обухова, О.В. Экологическая обусловленность факторов патогенности условнопатогенной микрофлоры 2016 г.

3. Тымчук С.Н. «Наиболее значимые санитарно-микробиологические показатели оценки качества питьевой воды» 2014 г.

4. Тымчук С.Н., Ларин В.Е., Соколов Д.М. «Водоснабжение и санитарная техника» 2014 г.

5. Борисова В.Ю., Кондакова Н.В., Хайсерова Л.Я. «Анализ повторного использования сточных вод в сельском хозяйстве» 2016 №8.

6. Трифонов О.В. «Оценка эффективности работы очистных сооружений по гидробиологическим показателям. Руководство по контролю за работой очистных сооружений биологической очистки сточных вод в аэротенках» 2016 г.

7. Ветошкин А.Г. «Инженерная защита гидросферы от сбросов сточных вод» 2016 г.

8. Яковлев С.В. «Канализация» 2014 г.

9. Федотова И.М., Белова Л.В., Карцев В.В. «Научно-практический журнал. Профилактическая и клиническая медицина» 2014 г.

10. Филимонова В.А. «Водоснабжение и водоотведение промышленных предприятий» 2017 г.

11. Сидорова Л.С., Снигерева А.Н. «Очистка сточных и промышленных вод» 2017 г.

12. Кольцов В.Б., Кольцова О.В. «Очистные сооружения часть $1 » 2016$ г.

13. Белюченко И.С. «Осадки сточных вод, их очистка и использование» 2016 г.

14. Вода России. Свердловская область. [Электронный ресурс] // Режим доступа: http://water-rf.ru/\%D0\%A0\%D0\%B5\%D0\%B3\%D0\%B8\%D0\%BE\%D0\%BD\%D1\% 8B_\%D0\%A0\%D0\%BE\%D1\%81\%D1\%81\%D0\%B8\%D0\%B8/2564/\%D0\%A1\%D0\% B2\%D0\%B5\%D1\%80\%D0\%B4\%D0\%BB\%D0\%BE\%D0\%B2\%D1\%81\%D0\%BA\%D 0\%B0\%D1\%8F_\%D0\%BE\%D0\%B1\%D0\%BB\%D0\%B0\%D1\%81\%D1\%82\%D1\%8C.

15. Государственный доклад «О состоянии и об охране окружающей среды Российской Федерации в 2016 году». - М.: Минприроды России; НИА-Природа. - 2017. - 760 с.

16. Проект государственного доклада «О состоянии и об охране окружающей среды Свердловской области в 2017». [Электронный ресурс] // Режим доступа: http://mprso.midural.ru/news/show/id/405. 


\title{
Vorobiyova Viktoriia Sergeevna \\ Ural state university of economics, Ekaterinburg, Russia College \\ E-mail: vorobeva053@gmail.com
}

Astratova Galina Vladimirovna

Ural state university of economics, Ekaterinburg, Russia E-mail: galina_28@mail.ru; astratova@yahoo.com

\section{Analysis of storm water systems and sanitary sewers: technical, organizational and economic aspects}

\begin{abstract}
The analysis of systems of storm and household Sewerage on the basis of research of some technical, organizational and economic aspects of activity of systems is carried out. It is shown that at the moment the problem of wastewater treatment is extremely relevant. It is established that many companies discharge a large amount of waste water, which is not actually treated in local reservoirs.
\end{abstract}

It is revealed that in the studied area in the Russian Federation as a whole and in the Sverdlovsk region, in particular, there is a failure to comply with the standards of treatment facilities. The key reasons for this situation are the following main factors:

1. physical deterioration of the equipment, unsatisfactory technical condition of treatment facilities;

2. mismatch of the composition of incoming wastewater and treatment systems;

3. lack of wastewater treatment facilities;

4. under-load on hydraulics and uneven flow of wastewater;

5. violation of technical and technological modes of operation of treatment facilities;

6. untimely carrying out of repair and restoration works, replacement of the failed equipment, units and parts;

7. lack of sufficient financing of the industry, financing on the "residual principle";

8. lack of highly qualified personnel for the implementation of competent operation of treatment facilities;

9. etc.

The authors believe that in order to improve the quality of wastewater discharged, reduce their impact on water bodies, reduce the volume of wastewater emissions, the following priority measures are needed:

a) construction of new, reconstruction and expansion of existing treatment facilities;

b) construction of local treatment facilities, post-treatment units;

c) commissioning of recycling and re-water supply systems;

d) identification of additional sources of financing for the treatment facilities system, including through concession agreements, the creation of private-public partnerships;

e) formation of "the state order" and allocation of target budgetary places in colleges and higher education institutions on training in the specialties connected with housing and communal services, water consumption and water disposal. 
Keywords: wastewater treatment; environmental hazards; drainage systems of the city; storm drains; domestic sewage; sewage treatment plants; storm and domestic sewage; Sverdlovsk region; water resources

\section{REFERENCES}

1. Vetoshkin A.G. (2016). Inzhenernaja zaschita gidrosfery ot sbrosov stochnyh vod. [Engineering protection of the hydrosphere from wastewater discharges.]

2. Obuhova O.V. (2016). 'Ekologicheskaja obuslovlennost' faktorov patogennosti uslovno-patogennoî mikroflory. [Ecological conditionality of pathogenic factors of opportunistic microflora.]

3. Tymchuk S.N. (2014). Naibolee znachimye sanitarno-mikrobiologicheskie pokazateli otsenki kachestva pit'evoř vody. [The most significant sanitary and microbiological indicators for assessing the quality of drinking water.]

4. Tymchuk S.N., Larin V.E., Sokolov D.M. (2014). Vodosnabzhenie i sanitarnaja tehnika. [Water supply and sanitary engineering.]

5. Borisova V.Ju., Kondakova N.V., Hajserova L.Ja. (2016). Analysis of the reuse of wastewater in agriculture, 8. (in Russian).

6. Trifonov O.V. (2016). Otsenka `effektivnosti raboty ochistnyh sooruzhenij po gidrobiologicheskim pokazateljam. Rukovodstvo po kontrolju za rabotoj ochistnyh sooruzhenij biologicheskoj ochistki stochnyh vod v a`erotenkah. [Assessment of the efficiency of sewage treatment plants on hydrobiological indicators. Manual for monitoring the operation of treatment plants for biological treatment of wastewater in aerotanks.]

7. Vetoshkin A.G. (2016). Inzhenernaja zaschita gidrosfery ot sbrosov stochnyh vod. [Engineering protection of the hydrosphere from wastewater discharges.]

8. Jakovlev S.V. (2014). Kanalizatsija. [Sewerage.]

9. Fedotova I.M., Belova L.V., Kartsev V.V. (2014). Nauchno-prakticheskiǐ zhurnal. Profilakticheskaja i klinicheskaja meditsina. [Scientific and practical journal. Preventive and Clinical Medicine.]

10. Filimonova V.A. (2017). Vodosnabzhenie i vodootvedenie promyshlennyh predprijatij. [Water supply and water disposal of industrial enterprises.]

11. Sidorova L.S., Snigereva A.N. (2017). Ochistka stochnyh i promyshlennyh vod. [Sewage and industrial water treatment.]

12. Kol'tsov V.B., Kol'tsova O.V. (2016). Ochistnye sooruzhenija chast' 1. [Wastewater treatment plant part 1.]

13. Beljuchenko I.S. (2016). Osadki stochnyh vod, ih ochistka i ispol'zovanie. [Sewage sludges, their purification and use.]

14. water-rf.ru. (n.d.). Water of Russia. Sverdlovsk region. [online] Available at: http://water-rf.ru/\%D0\%A0\%D0\%B5\%D0\%B3\%D0\%B8\%D0\%BE\%D0\%BD\%D1\% 8B_\%D0\%A0\%D0\%BE\%D1\%81\%D1\%81\%D0\%B8\%D0\%B8/2564/\%D0\%A1\%D0 $\% \mathrm{~B} 2 \% \mathrm{D} 0 \% \mathrm{~B} 5 \% \mathrm{D} 1 \% 80 \% \mathrm{D} 0 \% \mathrm{~B} 4 \% \mathrm{D} 0 \% \mathrm{BB} \% \mathrm{D} 0 \% \mathrm{BE} \% \mathrm{D} 0 \% \mathrm{~B} 2 \% \mathrm{D} 1 \% 81 \% \mathrm{D} 0 \% \mathrm{BA}$ $\% \mathrm{D} 0 \% \mathrm{~B} 0 \% \mathrm{D} 1 \% 8 \mathrm{~F}+\% \mathrm{D} 0 \% \mathrm{BE} \% \mathrm{D} 0 \% \mathrm{~B} 1 \% \mathrm{D} 0 \% \mathrm{BB} \% \mathrm{D} 0 \% \mathrm{~B} 0 \% \mathrm{D} 1 \% 81 \% \mathrm{D} 1 \% 82 \% \mathrm{D}$ $1 \% 8 \mathrm{C}$ (in Russian).

15. (2017). Gosudarstvennyj doklad «O sostojanii i ob ohrane okruzhajuschej sredy Rossijskoj Federatsii v 2016 godu». [State report "On the state and on the protection of the environment of the Russian Federation in 2016".] Moscow: Ministry of Natural Resources of Russia; NIA-Nature, p. 760.

16. mprso.midural.ru. (n.d.). Draft State Report on the State and Protection of the Environment of the Sverdlovsk Region in 2017. [online] Available at: http://mprso.midural.ru/news/show/id/405 (in Russian). 